\title{
機能的単腎症に扮ける腎細胞癌の治療経験
}

\begin{tabular}{cllll} 
& 岡 & 田 & 弘 \\
& 浜 & \multicolumn{1}{c}{ 見 } & & 学 \\
神戸大学医学部泌尿器科学教室 & 守 & 殿 & 貞 & 夫 \\
& 石 & 神 & 襄 & 次 \\
新日鉄広畑病院泌尿器科 & 岡 & 田 & 泰 & 長 \\
兵庫県立淡路病院泌尿器科 & 高 & 田 & 健 & 一
\end{tabular}

\section{A CASE REPORT OF A RENAL CELL CARCINOMA DEVELOPED IN A SOLE FUNCTIONING KIDNEY}

\author{
Hiroshi Okada, Gaku Hamami, Sadao Kamidono and Joji Ishigami \\ Department of Urology, Kobe University School of Medicine \\ (Director: Prof. J. Ishigami) \\ Yasunaga Okada \\ Department of Urology, Shinnitetsu Hirohata Hospital \\ Kenichi Takada \\ Department of Urology, Awaji Hospital, Hyogo Prefectural Government
}

A 62-year-old woman developed a renal cell carcinoma in her only functioning kidney. The contralateral kidney was not functioning due to congenital hypogenesis. She was treated successfully by simple enucleation of the tumor to spare the renal function as much as possible. 28 months after the operation she remains well with good renal function and without any signs of recurrence or metastasis.

A review of available literature revealed that there are 3 possible ways of treating a malignant tumor of a sole functioning kidney.

(1) radical nephrectomy + hemodialysis or renal transplant

(2) partial nephrectomy (in situ or ex vivo)

(3) enucleation of the tumor (in situ or ex vivo)

We discussed the advantages and disadvantages of each method.

要旨：機能的単腎者に発生した腎細胞癌の 1 例を経験したのでその治療経過を示すとともに文献的考察 を加えた。

症例は，62歳，女性. 無症候性肉眼的血尿を主訴として来院し，CT 䇽よび血管造影の結果, 左形成不 全腎および右腎下極に発生した腎実質性悪性腫瘍と診断された。経腹膜的アプローチにて，in situでの 右腎腫瘍核出術が施行された。阻血時間 60 分間, 摘出腫瘍重量 $80 \mathrm{~g}$, 病理組織診断では, clear cell type の腎細胞癌であった。術後 28 月たった現在，腎細胞癌の再発および転移の徴候はなく，残存腎機能も 良好である。

文献的考察によれば単腎者腎細胞癌の外科的治療は根治的腎摘出術十血液透析または腎移植, in situ または ex vivoの腎部分切除術あるいは腫瘍核出術が行なわれているがどの方法が最良であるかは未だ 結論が出ていない。

単腎者腎細胞癌の外科的治療の報告例は少なく, 本邦において本症例は 6 例めであり, 機能的単腎者 の腎細胞癌に対し, in situで腫瘍核出術が施行された女性としては第 1 例目であった。 


\section{緒言}

腎細胞癌に対する化学療法, 免疫療法あるいは放射 線療法の単独治療成績は不良であり, 現在でも本腫瘍 に対する治療は観血的手術治療に主眼がおかれてい る. 腎細胞癌の発生を見た患者に拈いて, 対側腎の機 能が保たれている場合には根治的腎摘術を第一選択と しているが, 両側の腎細胞癌症例や外科的または機能 的単腎症例に拈ける腎細胞癌の場合には根治的腎摘 出十透析または腎移植という方法と, 腎保存的手術法 のいずれを選択するかが問題となっている，我々は， 機能的単腎者に発生した腎細胞癌に対して in situで の腫瘍核出術を施行し，術後28力月たった現在，再発 徵候なく残存腎機能が正常である症例を経験したので その概略と若干の文献的考察を加えて報告する.

\section{症例}

62歳, 女性, 事務職.

主訴：無症候性肉眼的血尿.

現病歴：昭和 56 年 10 月，なんら誘因なく肉眼的血尿 が出現し, 膀腃タンポナーデとなり近医にて凝血塊除 去術を受けその後症状が無いため放置していた。同年, 12月29日, 再度無症候性肉眼的血尿が出現し膀胱タン ポナーデ, 尿閉となったため某病院泌尿器科に入院, 凝血塊除去術ならびに膀胼カテーテル留置をらけた。 この時の膀胼鏡検查にて膀胱内に異常所見はなかっ た，DIPにて左無機能腎および，右腎下極の造影欠損 を認め, 右腎動脈造影, CT 等により右腎腫瘍が強く疑 われたため, 昭和57年 2 月神戸大学医学部泌尿器科へ 転院した。

既往歴：20年前に腎盘腎炎，この活かに特記すべき ものはなかった。

家族歴：特記すべきものなし.

入院時現症：身長 $149.5 \mathrm{~cm}$, 体重 $46 \mathrm{~kg}$. 眼䀫球結膜 に貧血黄疸を認めず.頝部および Virchow リンパ節を 触知しなかった。胸部では，打聴診上心肺に異常は認 めなかった。腹部では，右腎を肋骨弓下に 2 横指触知 する他には特記すべき所見はなかった，右腎下極は表 面平滑で, 呼吸性移動は良好であり, 圧痛はなかった。 外性器に異常なく，四肢に浮腫等を認めなかった。

検査成績：検尿肉眼的血尿，白血球 $1 \sim 2 / \mathrm{hpf}$, タン パク (一), 糖 (一), 尿細胞診は 5 回とも class I であっ た。尿培養にて Citrobactor freundii $10^{5} / \mathrm{ml}$, 血液一 般検査で赤血球 $300 \times 10^{4} / \mathrm{mm}^{3}$, 白血球 $2,700 / \mathrm{mm}^{3}, \mathrm{Hb}$ $9.3 \mathrm{~g} / \mathrm{dl}$, 血小板 $18.8 \times 10^{4} / \mathrm{mm}^{3}$ であった. 出血時間 4 分, 凝固時間13分, プロトロンビン時間 12.2 秒, トロ
Fig. 1 DIP : 左腎は無機能で右腎は下腎杯の上方へ の軽度の圧排をみる

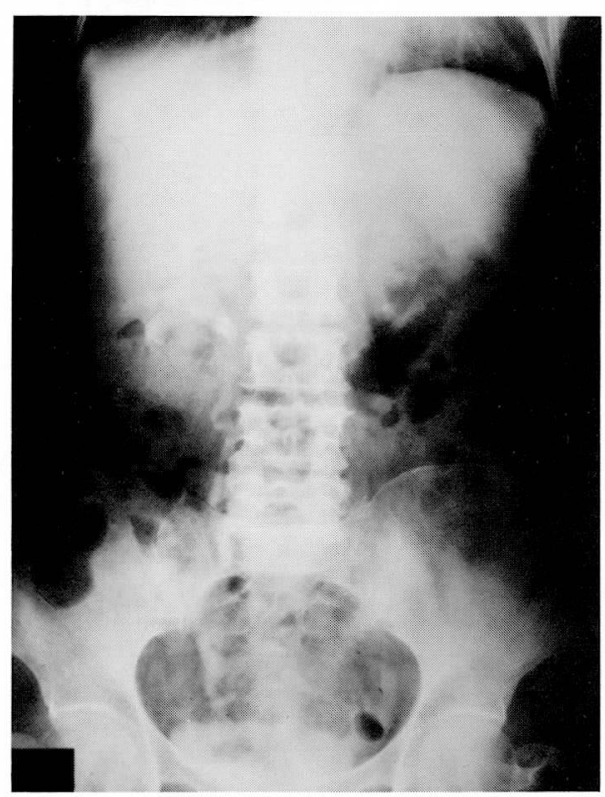

ンボプラスチン時間27.1秒であった。

血液生化学検査で GOT $12 \mathrm{IU} / l, \mathrm{CPT} 8 \mathrm{IU} / l$, Bil-T $0.5 \mathrm{mg} / \mathrm{dl}$, (Bil-D 0.1mg/dl), Chol. $248 \mathrm{mg} / \mathrm{dl}, \mathrm{LDH}$ $148 \mathrm{IU} / l$, CPK $17 \mathrm{IU} / l$, TP $7.3 \mathrm{~g} / \mathrm{dl}$, Alb $3.7 \mathrm{~g} / \mathrm{dl}$, BUN $15 \mathrm{mg} / \mathrm{dl}$, UA $3.2 \mathrm{mg} / \mathrm{dl}$, Creatinine $0.8 \mathrm{mg} / \mathrm{dl}$, $\mathrm{Na} 142 \mathrm{mEq} / l, \mathrm{~K} 4.1 \mathrm{mEq} / l$, Cl $105 \mathrm{mEq} / l$, Ca 10.7 $\mathrm{mg} / \mathrm{dl}$, 血糖 $99 \mathrm{mg} / \mathrm{dl}$, 血沈30分 $21 \mathrm{~mm}, 60$ 分 $52 \mathrm{~mm}, 120$ 分 $98 \mathrm{~mm}, \mathrm{CRP}(-), \mathrm{RA}(-)$, ASO $100 \mathrm{Todd} / \mathrm{U}$ 以 下, $\mathrm{Hb}$ 陰性, 梅毒血清反応陰性, $レ ニ ン$ 活性 $0.2 \mathrm{ng} / \mathrm{ml} /$ $\mathrm{hr}, \mathrm{CEA} 1.4 \mathrm{ng} / \mathrm{ml}$.

$\mathrm{X}$ 線学的検査

胸部単純：CTR 43\%，異常陰影を認めず.

腎膀胱部単純：骨陰影に異常はなく, 尿管走行部に 結石を疑わせる陰影はなかった，右腎の contourがや や不整であり，左腎の contour は不明である.

排泄性腎盂造影：左腎は無機能で, 右腎は軽度の水 腎症と下腎杯の上方への軽度の圧排がみられた（Fig. 1).

逆行性腎孟造影：左腎は萎縮しており, 腎杯の発達 不良で形成不全腎と考兄られた，右腎は腎下極の占拠 性病変によると思われる圧排所見がみられた（Fig. 2).

腹部 C.T. : 右腎下極に造影剂によって軽度 enhanceされる不均一な内容を有する占拠性病変を認める. 
Fig. 2 両側 RP：左腎は形成不全腎と考えられる像を呈し右腎は腎下極の占拠性病 変によると思われる圧排所見がある

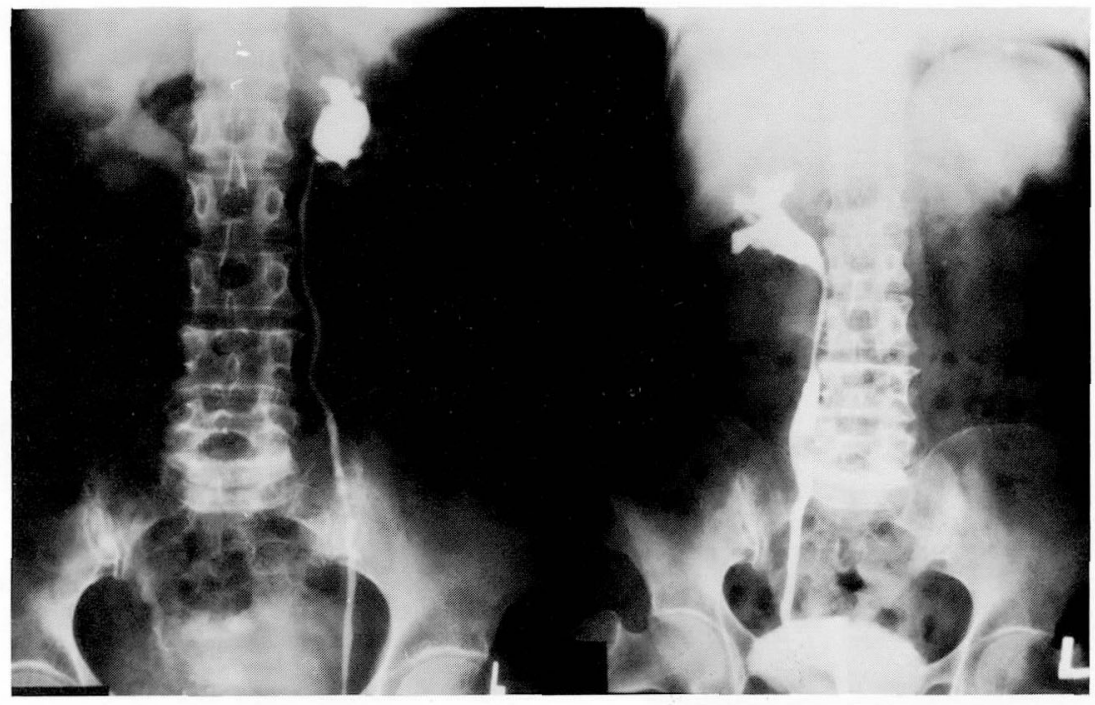

Fig. 3 腹部 CT：右腎下極に占拠性病変を認める

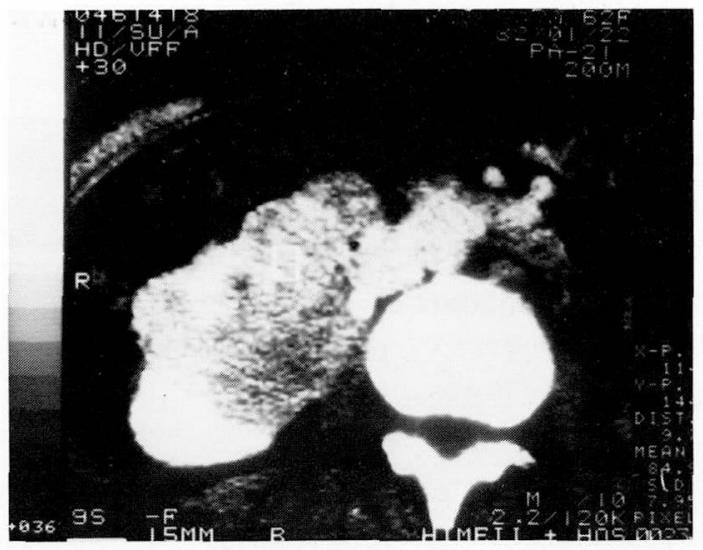

右腎静脈の内部には腫瘍血栓を思わせる所見はなかっ た (Fig. 3).

腹部大動脈造影：動脈硬化によると思われる大動脈 の屈曲蛇行を認め, 右腎下極に腫瘍血管像や pooling 像を伴なら占拠性病変が見られた。左腎動脈は起始部 で閉塞していた。腫瘍への栄養血管は右腎動脈からの 又と思われた（Fig. 4).

選択的右腎動脈造影：右腎下極の占拠性病変内に腫 瘍血管と思われる走行の不規則な血管陰影を認めた. nephrogram で pooling 像や右腎下極の contour の乱 れが認められた (Fig. 5).

以上ょり機能的単腎に発生した, 腎実質性悪性腫瘍
Fig. 4 腹部大動脈造影: 左腎動脈は起始部で閉塞, 右腎下極に腫瘍血管像を認める

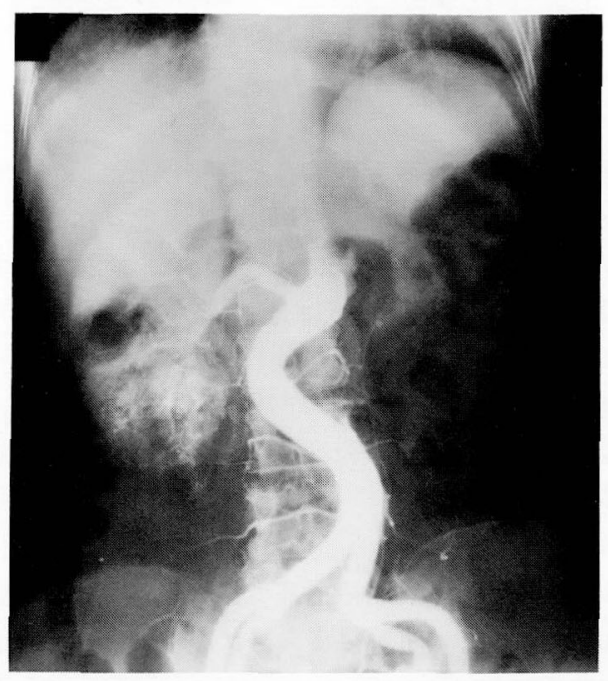

の診断のもとに，外科的治療が考慮された。 治療

術後の腎機能不全に備えて, 予め左前腕に内シャン ト造設術を施行した. シャントが blood acscess とし て使用可能であることを確認の上全身麻酔下に経腹的 アプローチにて右腎にいたり，マニトール負荷後 slushed ice にて regional cooling を行ない腎動脈を阻血 し, 右腎腫瘍核出術を施行した. Gerota’s fasciaには 
Fig. 5 選択的右腎動脈造影：右腎下極の占拠性病変 内に不規則な腫瘍血管陰影を認め卷

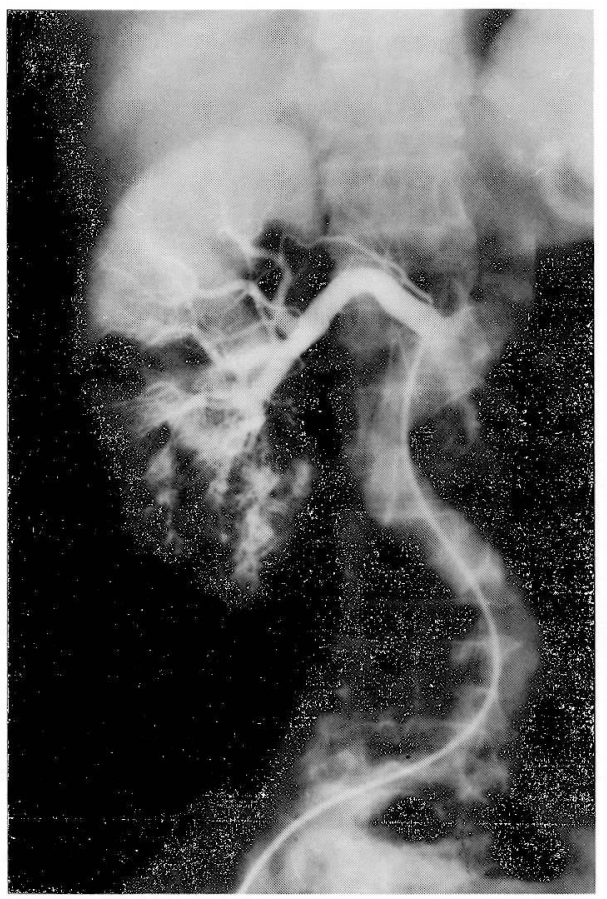

腫瘍浸潤を思わせるものはなく腫瘍は pseudocapsule に被覆されて蛙り，腎の健常組織とは容易に剥離され た。腫瘍は pseudocapsuleに覆われたまま摘出され た。摘出面に露出した太い血管は catgut にて縫合止血 された。

摘出腫瘍重量 $80 \mathrm{~g}$, 阻血時間60分であった。

術中迅速切片の病理組織診断で腎門部リンパ節には 転移を認めなかった。

病理組織学的検查

clear cell type の腎細胞癌で，腎被膜および腫瘍の pseudocapsule にも腫瘍浸潤はなかったため, stage l と診断された (Fig. 6)。

術後経過

BUN は術後 3 日目でピーク $(31 \mathrm{mg} / \mathrm{dl})$ に達し, 以 後潮減し16日目には正常化した。 また Creatinine も術

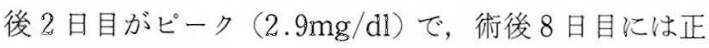
常値となったため (Fig. 7)，一度も血液透析はおこな われなかった。術後経過は良好であり術後28日目に退 院となった。退院後一過性にGOT, GPT の上昇を認 め血性肝炎と䛦断されたが, 肝庇護法により軽快した。 退院後, 外来にて経過観察されている。手術後28力月
Fig. 6 摘出腫瘍の病理組織：明かるい胞体を有する clear cell type の腎細胞癌

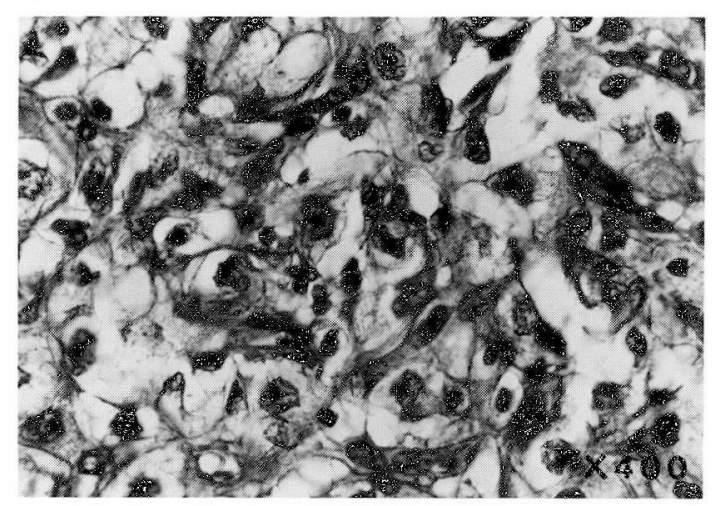

Fig. 7 術前, 術後の BUN, Creatinine の变化

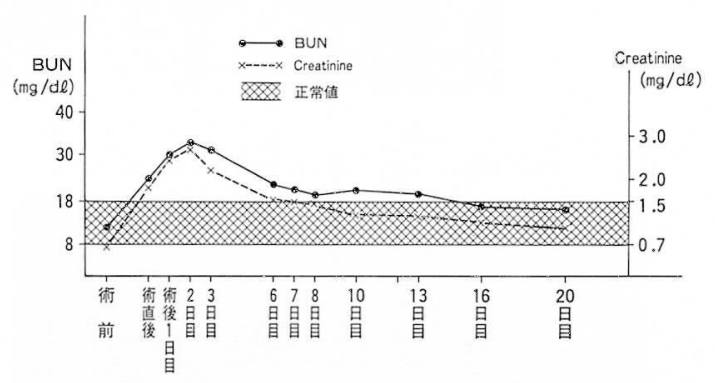

たった現在, 残存腎の機能は正常で DIP おょびCT 上 腎細胞癌の再発幑候はない。血液生化学的データにも 特記すべき所見はない, renin, erythropoietine 拈よび CEA はすべて正常範囲内である.

\section{考索}

集団検診の普及と超音波断層装置や $\mathrm{CT}$ 等の $\mathrm{ME}$ の進歩に伴ない, 手術可能な腎細胞癌の及かけの頻度 が増加するにつれ，単腎者に打ける腎細胞癌の症例報 告が増加している。

Table 1 単腎者の腎細咆癌に対する手術療法

1. radical nephrectomy

・術後透析

。腎移植

2. 腎保存的手術

- partial nephrectomy

in situ operation

ex vivo operation + autotransplantation

- enucleation of tumor in situ operation ex vivo operation + autotransplantation 
Table 2 本邦における単腎者の㹂細胞癌患者に対する腎保存的治療例

\begin{tabular}{|c|c|c|c|}
\hline 報 告 者 & 年龄，性別 & 単腎となった原因 & 残存腎に対する手術 \\
\hline 池田ら（1972） & 45嘁 & 腎結核で右婜摘 & in situ. partial nephrectomy \\
\hline 高橋ら （1979） & 50 歳 & 腎細胞癌で左腎摘 & in situ. 腫瘳核出術 \\
\hline 石川ら （1981） & 47藏 & 腎細胞癌で左腎摘 & ex vivo. partial nephrectomy \\
\hline 鈴木ら （1982） & 55歲 & 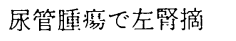 & ex vivo. 腫瘳核出術 \\
\hline Iizumi $5(1983)$ & 50 歳 & 腎結石で右婜摘 & in situ. partial nephrectomy \\
\hline 自験例 （1984） & 62 歳 & 左先天的形成不全堅 & in situ. 腫瘷核出術 \\
\hline
\end{tabular}

先天性単腎者の腎細胞癌症例の頻度は Ghosh ら ${ }^{11} に$ よれば, 1/770,000程度とされており非常にまれである が，外科的ならびに機能的単腎症者における腎細胞癌 の報告例は欧文，和文ともに散見される．

単腎者の腎細胞癌は根治的腎摘術，あるいは腎保存 的な方法により治療される(Table 1)，前者では根治 的腎摘術後に血液透析または腎移植を行なう。単腎者 であっても，腎細胞癌に対する最も有効な治療法は根 治的手術療法であるとの考光は悪性腫瘍の治療理論に 適ら 2)ものである.しかし, 透析患者や腎移植後の免疫 抑制療法中の潜在性悪性腫瘍の発現や新たな悪性腫瘍 の発生する危険性が高いとの報告があり，これは本症 に対して腎保存的手術が行なわれる一つの所以となっ ている ${ }^{3)}$.一方，免疫抑制療法は既に暴露された抗原に 対する免度応答を障害しないとの報告(4)，再発や免 疫学的背景の諸要因の影響を考虑して, 腎悪性腫瘍摘 除後 1 年以上の期間を扣いて腎移植を行なえば良いと の報告5すみられ，未だ統一した見解は得られていな いのが現状といえる。腎保存的方法のらち, 化学療法, 免疫療法打よび放射線療法は腎細胞癌に対していずれ も満足な成果は得られていないため, 腎保存的治療法 として腎部分切除術ならびに腫瘍核出術が採用されて きた。これには，それぞれ in situでおこなら方法と腎 を一度体外に取り出し腫瘍除去を行なったら首自腎 移植する ex vivo surgery (bench surgery) の両者が ある。腎部分切除術は，(1）腎細胞癌の $81 \%$ が㹂上極 または下極に発生するため，充分腫瘍部分を en bloc に切除しえる。（2）腎細胞癌は60歳以上に発生するこ とが多いため動脈硬化などのため腎移植の適応となら ないことが多い（3）腎摘後透析や腎摘後腎移植の場 合のように免疫能の低下がおこらない(3)，等の考学か たから行なわれている。

一方, 腫瘍の核出術を推奨する報告()は，その根拠と して腎細胞癌は pseudocapsule を形成する形で增殖 するため核出可能であり, 利点として, 可及的に多く
の健常な腎組織を残すことができること，止血が容易 なこと，手術術式が単純であることをあげている。

in situ と ex vivo surgeryを比較すると前者は後者 に比して手術手技が単純であり特殊な設備を必要とし ない、後者は前者に比して手術野が dry であり, 確実 な止血が可能である，また腎のいかなる部分の腫瘍に 対してでも腎保存的手術が可能と報告7されている.

Wickham ら ${ }^{71}$ は残腎の腎細胞癌に対し腎部分切除 術が施行された症例を他側腎の腎摘除の原因疾患によ り分類し，すなわち悪性腫瘍あるいは腎結核等の良性 疾患によるかの原因別に生存率を算定し，それぞれ 37\%抢よび68\%とのべている. また別に, 平均生存年 数はそれぞれ 3.2 年および7.6年との報告8)もある。

本邦における単腎者の腎細胞癌の腎保存的手術につ いての報告は少なく, 現在までに自験例を含め 6 例を 数光るのみ ${ }^{9) \sim 13)}$ である(Table 2)。このうち，2 例は in situの partial nephrectomy, 2 例は ex vivoの partial nephrectomy, 1 例は in situ の腫瘍核出術そ して 1 例は ex vivo の腫瘍核出術であった.

単腎の原因は 2 例が腎細胞癌で, 1 例が尿管腫瘍, 1 例が腎結核，そして1例は腎結石で腎摘をうけた外 科的単腎であった。いずれも男性であり年龄は $45 ５ 5$ 歳であった。本症例の単腎の原因は, 大動脈造影と左 逆行性腎盎造影の所見から先天性形成不全腎によると 考えられた。したがって, 本症例は先天性形成不全腎 による機能的単腎者に発生し, in situ で腫瘍核出術が おこなわれた腎細胞癌の, 女性の本邦第 1 例目である.

単腎者の腎細胞癌に対し前述の各種の外科的治療法 が行なわれているが，いずれも症例数が少なく，どの 方法が最良であるかは未だ結論がでていない.今後, 予後調査も含め症例の蓄積が必要である.

\section{まとめ}

単腎症例に発生した腎細胞癌の in situにおける腫 瘍核出術の経過について述べ, あわせて単腎症例の腎 細胞癌の治療法扰よび本邦における報告例に関して言 
及した。

$$
\text { 文献 }
$$

1) Ghosh, S.K. and Donegan, W.L.: Partial nephrectomy for carcinoma in a congenital solitary kidney. J. Urol., 104, 380-383, 1970.

2) Brannen, G.E., Correa, R.J. and Gibbons, R.P. : Renal cell carcinoma in solitary kidneys. J. Urol., 129, 130-131, 1983.

3) Novick, A.C., Stewart, B.H., Straffon, R.A. and Banowsky, L.H.: Partial nephrectomy in the treatment of renal adenocarcinoma. J. Urol., 118, 932-936, 1977.

4) Mannick, J.A., Lee, H.M. and Egdahl, R.H.: The effect of 6-mercaptopurine on immune responsiveness of the dog. Surg. Gyenc. Obstet, 449-457, 1962.

5) Penn, I.: Transplantation in patients with primary renal malignancies. Transplantation, 24, 424-434, 1977.

6) Graham, S.D. Jr. and Glenn, J.F.: Enucleative surgery for renal malignancy. J. Urol., 122, 546-549, 1979.

7) Wickham, J.E.A.: Conservative renal surgery for adenocarcinoma. The place of bench surgery. Brit. J. Urol., 47, 25-36, 1975.
8) Malek, R.S., Utz, D.C. and Culp, O.S.: Hypernephroma in the solitary kidney: Experience with 20 cases and review of the literature. J. Urol., 116, 553-556, 1976.

9) Ikeda, N., Tofukuji, H., Nakazono, M. and Katsuoka, Y.: Partial nephrectomy for renal cell carcinoma in a solitary kidney. Keio J. Med., 21, 41-47, 1972.

10）高橋美郎, 熊川健二郎, 熊 佳伸, 伊達智徳：単腎 者の腎腫瘍に対し腫瘍摘出を行なった 1 例。福島 医学雑誌，29，276-277， 1979.

11）石川博通，樀 政昭, 村井 勝, 畠 亮, 田崎 寛：残腎に発生した腎細胞癌の体外手術後急性腎 不全の治験例。 日腎誌，23，489-494，1981.

12）鈴木孝行, 深谷保男, 長沢正人, 白岩康夫：単腎者 腎癌に施行した ex. vivo surgery の 1 例。日泌尿 会誌, 73, 1366, 1982.

13) Iizumi, T., Takeshima, H., Umeyama, T., Ishikawa, S., Nemoto, S., Nemoto, R., Yazaki, T., Kanoh, S. and Koiso, K.: Renal cell carcinoma in a solitary kidney treated by partial nephrectomy case report and reviw of Japanese literature. Jpn. J. Clin. Oncol., 13, 727-732, 1983.

（1984年 6 月 25 受付） 